\title{
Czy podejście hermeneutyczne jest interpretacyjnym wytrychem? Diagnoza i propozycja w kontekście współczesnej prozy
}

\begin{abstract}
Szkaradnik Katarzyna, Czy podejście hermeneutyczne jest interpretacyjnym wytrychem? Diagnoza i propozycja w kontekście współczesnej prozy [ls a hermeneutical approach an interpretative pass key? A diagnosis and proposal in the context of contemporary prose]. „Przestrzenie Teorii" 30. Poznań 2018, Adam Mickiewicz University Press, pp. 259-275. ISSN 1644-6763. DOI 10.14746/pt.2018.30.13.
\end{abstract}

The paper is an attempt to reflect on whether hermeneutics can still be a cognitively fruitful approach in literary studies, especially in respect of contemporary output. The authoress analyses two currents in the literature, which could be named integrating and eristic. They seem to correspond with two paradigms in hermeneutics: affirmative, concentrating on "brightening an existence", and radical, emphasizing "weakness", "flux", "collapsing" etc. A key issue is the doubt whether applying the name "hermeneutics" is not in itself misleading, as it concerns diametrically opposed points of view. The authoress proposes her own understanding of hermeneutics as a perspective of reading literature, which "cling on" to the protagonists', author's and interpreter's experience. She also invokes the metaphors of scaffolding and house building, where the home is marked with an unrelenting "uneasiness" and lacks strong foundations, but does convey the situation of incessant common constructing the accidental and demanding protection of meaning.

KEYWORDS: radical hermeneutics, hermeneutics of affirmation, interpretation, contemporary prose, experience

Stawiam przed sobą śmiałe zadanie, zamierzam bowiem przeanalizować praktykę czytania literatury z perspektywy hermeneutycznej, nieraz przyjmowanej przez badaczy wbrew środowiskowemu mainstreamowi i z pewnym zażenowaniem, gdyż orientacja ta bywa uważana za anachroniczna. Mimo to, kiedy interpretatorowi tekstu brakuje zaplecza teoretycznego, niejeden usprawiedliwia się „postawą hermeneutyczna”, aczkolwiek przeważnie mamy wówczas do czynienia ze słusznie wykpiwaną tak zwaną hermeneutyką impresyjna. Pomysły takiej osoby może więc są przekonujące, ale pozbawione ugruntowania. Czy jednak ugruntowanie polega na przytoczeniu zestawu skrzydlatych słów guru danego kierunku? Na interesującym nas polu - choćby o prawdzie jako otwartości, o symbolu, który daje do myślenia, o fuzji horyzontów czy o wydarzaniu się bycia, aby w zgodzie z toposem skromności zakończyć wywód aforyzmem: „Zły to hermeneuta, który sobie 
wyobraża, że może lub że musi mieć ostatnie słowo"1. Ironizuję, lecz zarazem - parafrazując wieszcza - „mówię, bom smutna i sama pełna winy”. Poniższe rozważania traktuję zatem jako kontrolę rusztowań, po których również osobiście się poruszam.

\section{Czyja hermeneutyka za przewodnika?}

Powracam do wspomnianego pseudohermeneuty: skoro da się stwierdzić bez wątpliwości, że jego postawy nie sposób identyfikować z podejściem hermeneutycznym, to na czym się ono zasadza (jeśli poprzestać na gruncie badań literackich)? Naturalnie, w każdej książce poświęconej tej orientacji wymienione są wspólne założenia jej przedstawicieli - akcentowanie historycznego perspektywizmu, rozumienia jako modusu bycia, subiektywnych i kulturowych przedsądów itp. Ujęto je też między innymi w podręczniku Teorie literatury XX wieku, wszakże i w nim wprowadzenie do odnośnego rozdziału nosi tytuł Hermeneutyki². Dla każdego, komu temat nie jest zupełnie obcy, owa wielość stanowi truizm; dla praktyki interpretacji zdaje się wynikać z niej tyle, że należy deklarować, do czyjej wersji się sięga, i być gotowym na pytanie, dlaczego akurat do tej.

Zaryzykuję tezę, iż samo szukanie łączności ${ }^{3}$ między utworem a ramą teoretyczną lub perspektywą okazuje się w ostatecznym rozrachunku intuicyjne i oparte na swoistym zawierzeniu ${ }^{4}$, tymczasem zazwyczaj właśnie hermeneutykę oskarża się o arbitralność, metodologiczną dezynwolturę i brak stałych wytycznych. Jak przypomina Odo Marquard, teorie bazujace na „deszyfrowaniu” (także nowsze niż powszechnie inkryminowany strukturalizm) uparcie negują sytuację wstępnego rozumienia świata tekstu

${ }^{1}$ H.-G. Gadamer, Prawda i metoda. Zarys hermeneutyki filozoficznej, przeł. i wstęp B. Baran, Warszawa 2007, s. 757.

${ }^{2}$ Zob. A. Burzyńska, M.P. Markowski, Teorie literatury XX wieku. Podręcznik, Kraków 2006, s. 175.

${ }^{3} \mathrm{~W}$ łączności nie musi chodzić o korespondencję, nieraz bardziej inspirująca bywa lektura „pod włos” w duchu mistrzów podejrzeń, takich jak Nietzsche, Marks, Freud itp. - zob. P. Ricoeur, O interpretacji. Esej o Freudzie, przeł. M. Falski, Warszawa 2008, s. 39.

${ }^{4}$ Por.: „Radosna swoboda buszowania w magazynie $\mathrm{z}$ teoriami kiepsko maskuje oportunistyczny agnostycyzm, reaktywność teoretycznych modnisiów [...]. [Ta krytyka nie oznacza - K.Sz.] nostalgii za Teorią Jedyna, ale wyraża niezgodę na twierdzenie, że teorie sa zestawem dla dowolnego używania [...]. Jeśli teoria zawsze już jest, a my przez to - zawsze $w$ jakiejś sytuacji teoretycznej, to jedynie w części jest ona naszym wyborem [...]. Teorię nie tylko się wybiera, lecz się jej zawierza i/lub praktykuje, a najważniejszy składnik tej praktyki znajduje się poza zasadą racjonalności” - R. Koziołek, Teoria literatury jako akt wiary, [w:] Teoria nad-interpretacja?, red. J. Olejniczak, M. Baron, P. Tomczok, Katowice 2012, s. 15. (Wszystkie wyróżnienia w cytatach moje - K.Sz.) 
i świata społecznego, czyli punkt wyjścia hermeneutyki, dla której „instan-

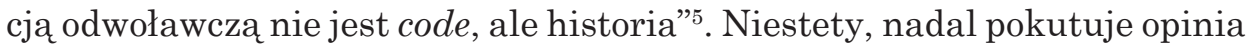
zawarta chociażby w Poetyce stosowanej z 2000 roku, że „hermeneutyka nie wypracowała własnych metod badawczych i korzysta albo z tradycyjnego instrumentarium literaturoznawczego, albo [...] w ogóle pomija etap analizy i roztapia proces interpretacji i «wyjaśniania» w powodzi uduchowionych i szlachetnych słów”.

\section{"O(d)słanianie świata"}

Wytykanie hermeneutyce pięknoduchostwa i patosu nie jest całkiem bezpodstawne - daje ku temu asumpt nie tylko retoryka „prawdy bycia”, ale nawet sformułowania, iż czytelnik „otrzymuje od tekstu nowy sposób istnienia" itp. Szczególnie narażona na zarzut idealizmu wydaje się pojednawczo-wzniosła wersja hermeneutyki, w której koncepcja rozmowy Gadamera splata się z teoriami potrójnej mimesis i tożsamości narracyjnej Ricoeura oraz wybranymi wątkami z pism Heideggera. Można taka „hermeneutykę afirmatywną" aplikować do sporej części współczesnej polskiej prozy - utworów ukazujących docieranie bohaterów do wglądu w siebie lub w „istotę rzeczy”, obłaskawianie przemijania, nabieranie identyfikacji z historią rodzinna, rozpoznawanie „linii losu” pomimo jej meandryczności. Narratorem tego typu Bildungsromane często jest człowiek dojrzały, zwracający się wstecz, by w świetle aktualnej świadomości usystematyzować własne doświadczenia.

Analizowany nurt egzemplifikuje choćby Traktat o tuskaniu fasoli Wiesława Myśliwskiego. Sam pisarz w jednym z wywiadów jakby cytuje Gadamera: „Świat istnieje [...] w języku. Prawdziwym przekazem językowym jest żywa mowa”, z kolei dalsze zwierzenie: „Ta książka wie więcej o mnie niż ja o niej” przywodzi na myśl zarówno uwagę, że sensy dzieła przekraczaja intentio auctoris, jak i ideę Ricoeura dotyczącą poszerzania jaźni dzięki obcowaniu ze światami otwieranymi przez tekst ${ }^{9}$. W omawianym przypadku

${ }^{5}$ O. Marquard, Pytanie o pytanie, na które odpowiedzia jest hermeneutyka, [w:] tegoż, Rozstanie z filozofia pierwszych zasad. Studia filozoficzne, przeł. K. Krzemieniowa, Warszawa 1994, s. 148.

${ }^{6}$ B. Chrzastowska, S. Wysłouch, Poetyka stosowana, Warszawa 2000, s. 29.

${ }^{7}$ P. Ricoeur, Przyswojenie, [w:] tegoż, Język, tekst, interpretacja. Wybór pism, wybór i wstęp K. Rosner, przeł. P. Graff, K. Rosner, Warszawa 1989, s. 287.

${ }^{8}$ Relacja z rozmowy T. Cichockiego z W. Myśliwskim podczas promocji książki Traktat o tuskaniu fasoli w klubie Razzy Dazzy Jazz w Krakowie 15.05.2006 r., Magazyn Studentów „Semestr”, <http://www.semestr.pl/2,2117.html> [dostęp: 16.07.2016].

${ }^{9}$ Zob. P. Ricoeur, Przyswojenie..., s. 273. 
warunkiem staje się wejście w rolę adresata monologu wypowiedzianego bezimiennego protagonisty. Dokonana przez Jerzego Jarzębskiego charakterystyka tego aspektu Traktatu... mogłaby stanowić komentarz do pism obu przywołanych hermeneutów:

U Myśliwskiego wszystko [...] rozgrywa się w gadaniu, które szuka sobie rozumiejącego odbiorcy. [...] egzystencja ludzka polega na czytaniu znaków i rozpoznawaniu porządków. Tego samego żąda pisarz od swego czytelnika, któremu zadaje losy swego bohatera niby wielką łamigłówkę, której sens trzeba zrozumieć, porównując fakty i sytuacje, a co najważniejsze - rozpoznając etyczny wymiar bytu ${ }^{10}$.

Wzmianka o czytaniu znaków potwierdza, że sygnalizowany wgląd w siebie nie jest domniemaną bezpośredniością cogito, lecz Ricoeurowska „droga okrężna”. Mianowicie interpretacja - jak by powiedział Dilthey obiektywizacji życia, czyli opowiadań, w których możemy się przeglądać niczym w przymierzalni ${ }^{11}$, oraz na przykład artefaktów będących korelatami kultury i historii konkretnej społeczności, jak w literaturze małych ojczyzn tudzież tak zwanej prozie korzennej ${ }^{12}$. Odzyskiwanie „korzeni” zachodzi w niej w efekcie (re)konstrukcyjnej mocy pamięci i słowa, co lokuje ją we wspólnym nurcie z takimi kamieniami milowymi XX-wiecznego powieściopisarstwa, jak fascynujący Ricoeura cykl Prousta czy Do latarni morskiej Virginii Woolf. Oba dzieła unaoczniaja materię przemijającego czasu, który nie tylko „nicościuje” (Heidegger), ale także pozwala dojrzeć do epifanii, czego doświadczają i Marcel, i malarka Lily Briscoe: „Z nagłym napięciem, jakby przez chwilę dane jej było bezbłędne widzenie, przeciagnęła pędzlem przez środek płótna. Dokonała tego, co chciała" ${ }^{13}$. Jej długoletnie poszukiwania formy wyrazu w połączeniu z użytą w powieści techniką punktów widzenia współbrzmią z hermeneutycznymi ideami, odpowiednio, nieprzejrzystości bycia oraz nieistnienia nieuwarunkowanego, wszechogarniającego obserwatora. Dlatego też epifania nie następuje samoczynnie, poprzedza ją mozolne strukturyzowanie przez postacie rzeczywistości, wtórne obdarzanie minionych momentów sensem.

Z pozoru sprawy komplikuja się w tekstach powikłanych kompozycyjnie, lecz sam Ricoeur replikował adwersarzom, którzy uważali tezy z Czasu

${ }^{10}$ J. Jarzębski, „Traktat o tuskaniu fasoli” W. Myśliwskiego, <www.instytutksiazki.pl/ ksiazki-detal,literatura-polska,1957,traktat-o-luskaniu-fasoli.html> [dostęp: 16.07.2016].

${ }^{11}$ Por.: ,[O]powiadania [w trzeciej osobie - K.Sz.] składają się na niewyczerpany skarbiec, z którego zapożyczamy niezliczone wzorce samozrozumienia, [...] laboratorium eksperymentów myślowych, które [...] możemy zastosować wobec samych siebie” - P. Ricoeur, Tożsamość osobowa, [w:] tegoż, Filozofia osoby, przeł. M. Frankiewicz, Kraków 1992, s. 41.

${ }^{12}$ Zob. na przykład P. Czapliński, Mapa, córka nostalgii, [w:] tegoż, Wznioste tęsknoty. Nostalgie w prozie lat dziewięćdziesiatych, Kraków 2001, s. 105-128.

${ }^{13}$ V. Woolf, Do latarni morskiej, przeł. K. Klinger, Warszawa 1962, s. 311. 
i opowieści za adekwatne tylko do „klasycznej” narracji, iż fabuła nie musi biec linearnie, a (post)modernistyczne eksperymenty nie dowodzą braku organizacji temporalnej ${ }^{14}$. Czy jednak jego rozumienie tożsamości bohatera nie wtłacza jej w model historii uspójniającej, teleologicznej, w obrębie której rzekome przypadki jawią się jako nieodzowne dla stania się tym, kim już się potencjalnie było ${ }^{15}$ ? Taką integrację obrazuje na przykład dygresyjna Lala Jacka Dehnela, saga rodzinna osnuta wokół reminiscencji babki narratora. Wprawdzie równoległym wątkiem jest postępująca destrukcja fizyczna i umysłowa owej kobiety, ale z mozaiki, jaką tworzą wydarzenia bieżące (opieka nad babcia) oraz dawne (coraz bardziej zagarniające świadomość staruszki), wyłania się „zgodna-niezgodna synteza”16. Hermeneutyczne „odsłanianie świata" okazuje się dwojakim ostanianiem: albo jego pęknięć, albo siebie przed jego cierniami; przemijanie wpisane zostaje w czas mityczny, zarazem kolisty i nieruchomy: „I tak całość się wypełnia. Właśnie się rodzę. I kończę książkę. Zresztą [...] wszystko to się i tak działo naraz - i nawet teraz, kiedy już za chwilę zamkniecie okładki, woźnica na Ukrainie odwraca głowę od wielkich renklod [...]. A słońce wschodzi na wschodzie, na zachodzie zachodząc" ${ }^{17}$. W podobnych utworach ukojenie nostalgii staje się możliwe dzięki zniwelowaniu przepaści między teraźniejszością a przeszłością lub stwierdzeniu braku takiej luki.

\section{Przepracować historię}

$\mathrm{Z}$ pozoru zbliżone rozpoznanie pobrzmiewa w inicjalnym zdaniu powieści Ciemno, prawie noc Joanny Bator: „Poruszałam się po śladach zostawionych przed laty, zdziwiona, że moje stopy ciagle do nich pasuja”" ${ }^{18}$. W tym wypadku jednak dochodzi raczej do rozpoznania demonów wypartych w tytułową ciemność, którą prawda nie zawsze rozprasza. Przed rozpatrzeniem takiego typu prozy trzeba zapytać, czemu ze stanowiska hermeneutyki „służy” literatura. Oczywiście, o odpowiedzi przesądza wybór reprezentanta oma-

${ }^{14}$ „Sądzić, że zerwało się z czasem fikcji, ponieważ się poprzestawiało, ponaginało [...] modalności czasowe [...], to tyle, co sądzić, że jedynym pojmowalnym czasem jest właśnie czas chronologiczny" - P. Ricoeur, Czas i opowieść, t. 2: Konfiguracja w opowieści fikcyjnej, przeł. J. Jakubowski, Kraków 2008, s. 45.

${ }^{15}$ Zob. A. Burzyńska, Kariera narracji. O zwrocie narratywistycznym w humanistyce, [w:] Narracja i tożsamość, t. 2: Antropologiczne problemy literatury, red. W. Bolecki, R. Nycz, Warszawa 2004, s. 20-24.

${ }^{16}$ Zob. na przykład P. Ricoeur, O sobie samym jako innym, przeł. B. Chełstowski, oprac. M. Kowalska, Warszawa 2003, s. 244.

${ }^{17}$ J. Dehnel, Lala, Warszawa 2006, s. 403.

${ }^{18}$ J. Bator, Ciemno, prawie noc, Warszawa 2013, s. 7. 
wianej orientacji. Według Gadamera fundamentalny impuls do tworzenia form lub uczestnictwa w ich grze - a więc także do tworzenia i odbioru beletrystyki - daje chęć zatrzymania tego, co przemija ${ }^{19}$. Taki motyw ilustruje ekspansja quasi-autentyku oraz literatury odwołującej się do pamięci komunikacyjnej i kulturowej ${ }^{20}$, przy czym pamięć staje się zobowiązaniem wobec Innego. W Ocaleniu Atlantydy Zyty Oryszyn babka zwraca się do wnuczki Oli: „Teraz [...] jesteś moim jedynym schronem, nie ty musisz się chować, lecz mnie przechować [...]. Niedługo umrę i zostanie wtedy ze mnie i mojego świata tylko tyle, ile zapamiętasz" ${ }^{21}$. Patos owego polecenia przełamuje reakcja dziewczynki, która „Aż zesztywniała ze strachu. Jak to: ma być czyimś schronem. Schrony zwykle są za małe nawet na jedną osobę, cuchną strachem i śmiercią".

Skojarzenia wnuczki trafniej oddaja klimat przywołanej powieści, zogniskowanej na powojennych realiach Ziem Zachodnich i życiu ich nowych mieszkańców - życiu w permanentnym strachu, w atmosferze beznadziei i terroru. Postacie o „złym” pochodzeniu lub „niepoprawnej politycznie” przeszłości muszą się kamuflować, porzucić własną tożsamość; wśród sąsiadów próżno liczyć na krztę solidarności, panuje psychoza donosów, a przedstawiciele różnych warstw społecznych nigdy się nie porozumieja. Narracja jest prowadzona z perspektywy częściowo naiwnej, ale zarazem podszyta ironią i sarkazmem, które wydobywają kuriozalność i nieprzewidywalność rzeczywistości. W jednym z epizodów okupacyjnych pada konstatacja, że Polska to „podły kraj. Bezustannie trwa w niej polowanie, ktoś kogoś goni, ktoś gdzieś ucieka" ${ }^{2}$, czego świadectwo przynoszą wszystkie wątki fabularne, sięgające aż po lata osiemdziesiąte.

Co w takim razie poczaćć, skoro „Nigdy nikt się stąd nie wymknie”23? W tej sytuacji ze świata przedstawionego przenosimy się na wyższa płaszczyznę, na której następuje konfrontacja autora i czytelnika z historia, przy czym ze względu na upiorność minionego celem wydaje się nie tyle „zatrzymanie tego, co przemija”, ile - jak zdefiniował zadanie hermeneutyki Marquard - „dokonywanie zmian tam, gdzie nie można niczego zmienić: tam zatem [gdzie] trzeba właśnie czynić coś zamiast czegoś, czyli interpretować" ${ }^{24}$. Czy jednak taka mentalna transformacja ma doniosłość w wy-

${ }^{19}$ Zob. H.-G. Gadamer, Aktualność piękna. Sztuka jako gra, symbol i święto, przeł. K. Krzemieniowa, Warszawa 1993, s. 62.

${ }^{20}$ Zob. na przykład J. Jarzębski, Kariera „autentyku”, [w:] tegoż, Powieść jako autokreacja, Kraków 1984, s. 337-364; A. Assmann, Cztery formy pamięci, przeł. K. Sidowska, [w:] tejże, Między historiq a pamięcia. Antologia, red. M. Saryusz-Wolska, Warszawa 2013, s. 39-57.

${ }^{21}$ Z. Oryszyn, Ocalenie Atlantydy, Warszawa 2012, s. 25.

${ }^{22}$ Tamże, s. 8.

${ }^{23}$ Tamże, s. 18.

${ }^{24}$ O. Marquard, dz. cyt., s. 129. 
miarze empirycznym? Gotowość do roztropnego stawienia czoła przeszłości niewątpliwie stanowi warunek reorientacji instytucjonalnej polityki pamięci w kwestii rozmaitych wstydliwych zaszłości. Zdaniem Marka Szulakiewicza hermeneutyka uczy żyć w labilnym i pluralistycznym świecie, uwypuklając „koniecznoś[ć] budowania stale nowego jego obrazu. Wolność i otwartość, które często odnoszone były tylko do przyszłości, za sprawą hermeneutyki odnajdywane są również w przeszłości” ${ }^{25}$. Niestety, szeroki społeczny efekt przepracowywania historii w medium literatury jawi się jako utopijny, wypada więc pozostać przy indywidualnych egzemplifikacjach tego, jak interpretacyjne przeobrażenie traumatycznej przeszłości wiedzie do realnej zmiany.

Takim przykładem dotyczącym - co sugerują sygnały paktu autobiograficznego - nie tylko bohaterki, lecz i autorki byłyby dwie ostatnie książki Magdaleny Tulli. „,[U]przytomniłam sobie, że gdyby naprawdę zabrakło mi przyszłości, już bym nie żyła. Więc zostało jej jeszcze trochę, [...] lekko licząc trzydzieści lat. Trzydzieści lat dobrego życia, wystarczy po nie sięgnąc’”26 wyznaje narratorka Wtoskich szpilek. Od dzieciństwa wielorako wyalienowana, cierpi ona tyleż wskutek powszechnej degrengolady i frustracji, pokłosia wojny, co z powodu toksycznej matki, Żydówki, która straciwszy w obozie koncentracyjnym całą rodzinę, nie uporała się z trauma. Narratorka - nosicielka postpamięci - musi przeto również za nią zmierzyć się z minionym w duchu Marquardowskiej hermeneutyki „kompensuj[ącej] niemożność unicestwienia przeszłości możnością zdystansowania się od niej”"27. W Szumie czytelnik śledzi autoterapię opartą na rozpoznaniu przyczyn własnego położenia, następnie zaś na próbach oczyszczenia relacji z innymi, tak by zaistniała prawdziwa komunikacja, a błędne koło niedomówień i obojętności przemieniło się w hermeneutyczne koło (z)rozumienia.

$\mathrm{W}$ tej formule uzdrawiającego reinterpretowania historii kluczowa okazuje się wiara w ocalającą siłę pamięci i literatury. Dla „pozatekstowej” Tulli-autorki pomocne w zrzucaniu brzemienia przeszłości staje się pisanie, lecz warto nadmienić, że pozbawione szansy innego ratunku postacie $\mathrm{z}$ opowiadań Oryszyn także upatruja go w słowie pisanym. W poniższym wyimku mowa o zwykłej komórce, ale będącej zapewne metaforą książki, w której ów cytat się mieści i która „ocala” bohaterów, nie zakłamując ich niedoli: „To był jej i Poety Przeklętego schowek. - Pisz - mówił Poeta - pisz i tu składaj, co napiszesz, a kto by tu zaglądał. Ja tu składam swoje wiersze i zapiski: światełka nadziei rozjarzające labirynty strachu i upodlenia" 28 .

\footnotetext{
${ }^{25}$ M. Szulakiewicz, Filozofia jako hermeneutyka, Toruń 2004, s. 277-278.

${ }^{26}$ M. Tulli, Wtoskie szpilki, Warszawa 2011, s. 51.

${ }^{27}$ O. Marquard, dz. cyt., s. 130.

${ }^{28}$ Z. Oryszyn, dz. cyt., s. 264.
} 


\section{Dwa paradygmaty czy dwie fazy?}

Dotychczas - chociażby pytając o funkcje literatury - odnosiłam się do nurtu, który za Ricoeurem można określić mianem hermeneutyki zawierzenia, rekolekcyjnej ${ }^{29}$ lub afirmatywnej, a przecież na wstępie podkreślałam, że ilu hermeneutów, tyle hermeneutyk. Dla celów heurystycznych pozwolę sobie jednak na potrzeby niniejszych rozważań wyróżnić jej dwie główne odmiany, korespondujące z dwiema dominantami literatury, w tej współczesnej może szczególnie wyrazistymi. Proza w rodzaju Traktatu... Myśliwskiego wyrasta z inklinacji mitograficznych, dążenia do scalania, restytucji sensu; jej rewersem byłby „czarny nurt” ${ }^{30}$ ukazujący chaos, nietożsamość, rozpad jako nieusuwalne znamiona bycia-w-świecie. Owe rozbieżne tendencje w literaturze, ale też - szerzej - w światopoglądzie (pokrywające się z Heideggerowskim podziałem na „światowość” i „ziemskość”) ${ }^{31}$, Michał Paweł Markowski nazywa perspektywą eklezjastyczną i erystyczną vel metafizyczną i historyczna ${ }^{32}$. Niemniej akcentowanie dziejowości w opozycji do transcendentalnego stanowiska metafizyki nie przeszkadzało Ricoeurowi czy Gadamerowi skłaniać się ku opcji eklezjastycznej. Dla autora Prawdy i metody rozmowa, do której zapraszają nas wytwory kultury, umożliwia dostrzeżenie „trwałej postaci rzeczy” oraz „oswajanie się ze światem” ${ }^{33}$, a jak przekonuje on w Aktualności piękna, ,jeśli naprawdę doświadczyliśmy sztuki, to świat stał się lżejszy i więcej jest w nim światła" ${ }^{34}$.

Na przeciwległym biegunie sytuowałaby się hermeneutyka ponowoczesna czy radykalna Johna D. Caputo i Gianniego Vattima, bliska dekonstrukcyjnym aspektom myśli Heideggera i Derridy, kładąca nacisk na nietrwałość i niepewność - na ontologię „upadania”, gdyż zdaniem autora Końca nowoczesności „taka koncepcja bytu, życiowo-upadająca, tzn. śmiertelna, [...] lepiej oddaje znaczenie doświadczenia w świecie, w którym [...]

${ }^{29}$ Zob. P. Ricoeur, Konflikt hermeneutyk: epistemologia interpretacji, przeł. J. Skoczylas, [w:] tegoż, Egzystencja i hermeneutyka. Rozprawy o metodzie, oprac. S. Cichowicz, Warszawa 1985, s. 133-134.

${ }^{30}$ Zob. M.P. Markowski, Czarny nurt: Gombrowicz, świat, literatura, Kraków 2004.

${ }^{31} \mathrm{Na}$ przykład Vattimo w nawiązaniu do Heideggerowskiej refleksji nad prawdą dzieła sztuki podkreśla właśnie jego aspekt „ziemski” (skończoność, śmiertelność, skrytość), umniejszając rolę „światowego" (odkrycie nowych horyzontów egzystencji) - zob. G. Vattimo, Rozbicie słowa poetyckiego, [w:] tegoż, Koniec nowoczesności, przeł. M. Surma-Gawłowska, wstęp A. Zawadzki, Kraków 2006, s. 64-69.

${ }^{32}$ Zob. M.P. Markowski, Historia i metafizyka, [w:] Teraźniejszość i pamięć przeszłości. Rozumienie historii w literaturze polskiej XX i XXI wieku, red. H. Gosk, A. Zieniewicz, Warszawa 2006 , s. $44-45$.

${ }^{33}$ Zob. H.-G. Gadamer, Sztuka i naśladownictwo, przeł. M. Łukasiewicz, [w:] tegoż, Rozum, słowo, dzieje. Szkice wybrane, wybór, oprac. i wstęp K. Michalski, Warszawa 1979, s. 136.

${ }^{34}$ Tenże, Aktualność piękna..., s. 34. 
nie ma już [...] rozróżnienia pomiędzy pozorem a bytem”35. We współczesnej literaturze osłabienie substancjalności bytu manifestuje się albo jako „zanikanie treści świata", albo jako rzeczywistość tandetna, wybrakowana ${ }^{36}$. W obu wariantach nabiera wagi kategoria śladu, będącego tyleż reliktem (wydźwięk pozytywny), ile przejawem ubożenia, ułomności, zaniku, a także heterogeniczności, której literacki wyraz stanowiłyby parodie, pastisze, różnego typu „przepisywanie” tradycji ${ }^{37}$.

Jednak ślady odsłaniają swą złudność i pokrętność - ani bohaterów, ani interpretatora nie wiodą ku integracji sensu, lecz skazują na błądzenie, a odpowiadająca im hermeneutyka nie może być wspomnianym przewodnikiem, Hermesem, który sumiennie dostarcza czytelną wiadomośćc ${ }^{38}$. Daremnie tu liczyć na optymistyczny powrót do siebie „drogą okrężną”. Jonathan Culler pyta retorycznie, czy wiedza, jaka rzekomo przynosi ze sobą narracja, nie stanowi wyłącznie rezultatu naszych pragnień ${ }^{39}$, aczkolwiek hermeneutyka od dawna przestrzega przed narzucaniem tekstowi widzimisię interpretatora. Jak przypomina Paweł Kuligowski, „czytanie jest sprawdzaniem, czy to, co wiedziałem, jest tym, co wiem. [...] Rozumienie tekstu nigdy nie jest rozumieniem tego, co chciało się rozumieć - na tym polega zasadnicza negatywność doświadczenia hermeneutycznego" ${ }^{40}$. Wszakże mimo wszystko mamy instynkt porządkowania wyślizgującej się rzeczywistości, wiązania znaków w sensowny ciag, niczym w Imieniu róży Umberta Eco czy w Kosmosie Witolda Gombrowicza. W tej drugiej powieści jedyna zdobyta samowiedza napawa grozą (którą uosabia monstrualnie podświetlona latarką wśród nocy twarz Leona Wojtysa oświadczającego: „Innych widoków nie ma”), a próby usilnego wprowadzania konsekwencji w niezborny świat skutkują tragedią. W Imieniu róży autor, robiąc aluzję do Wittgensteina, wkłada w usta zakonnika-racjonalisty Wilhelma porównanie tworzonych przez umysł teorii do drabiny, którą po użyciu należy odtrącić - gdyż były pozbawione sensu.

Odzwierciedleniem takiego nastawienia są często utwory uwidaczniające krach metafizycznych pewników poprzez rozkład języka, poetykę koszmaru i halucynacji. Chaotyczna forma artystyczna bywa jednak myląca - na przykład w Siostrze Jáchyma Topola zdaje się służyć konstrukcji prywatnego

${ }^{35}$ G. Vattimo, Jenseits vom Subject, cyt. za: M. Potępa, Nihilizm i hermeneutyka $w$ filozofii G. Vattimo, [w:] Uniwersalny wymiar hermeneutyki, red. A. Przyłębski, Poznań 1997, s. 99.

${ }^{36}$ A. Zawadzki, Literatura a myśl słaba, Kraków 2009, s. 255.

${ }^{37}$ Zob. tamże, s. $145-146$.

${ }^{38}$ Zob. J.D. Caputo, Radical Hermeneutics. Repetition, Deconstruction and the Hermeneutic Project, Indianapolis 1987, s. 153-186.

${ }^{39}$ Zob. J. Culler, Teoria literatury, przeł. M. Bassaj, Warszawa 1998, s. 109.

${ }^{40}$ P. Kuligowski, Humanistyka jako hermeneutyka, Wrocław 2007, s. 290-291. 
mitu o odysei w poszukiwaniu partnerki duchowej. Zdecydowanie dalej idzie Samuel Beckett, w którego prozie załamanie się słowa osiaga ekstremum.

Ta filozofia pisarska - odrzucająca wszystko, czego człowiek dotąd bronił, łącznie z jego antropocentrycznymi uroszczeniami - wiedzie więc ku maksymalnemu redukcjonizmowi już nie tylko technik narracyjnych i stylu, ale języka jako takiego. [...] [Ostatecznie autor Nienazywalnego dochodzi - K.Sz.] do próby uchwycenia słowem owej ciszy wokół człowieka, totalnej i nieuniknionej, która człowiek usiłuje zaklać swym wątłym głosem i która go pochłania bez reszty ${ }^{41}$.

Skontrastowanych powyżej nurtów nie sposób utożsamić z podziałem na sztukę nowoczesną i ponowoczesna, bo czyż literatura modernistyczna nie przekroczyła już optyki metafizycznej i nie wydała dzieł reprezentatywnych dla paradygmatu erystycznego, takich jak Jadro ciemności albo Proces? ${ }^{42}$ Co więcej, obie tendencje moga występować u jednego autora, czego przykładu dostarcza pisarstwo Jerzego Pilcha. W Tysiqcu spokojnych miast antidotum na obłęd historii i polityki wydają się cykliczność i obrządek, rytuały dnia powszedniego oraz izolacja wspólnoty ewangelików; nawet śmierć ojca narratora jest oswajana przez szukanie dla niej porządku logicznego, mianowicie omenów, które ją zapowiadały. W późniejszych Wielu demonach króluje widmo upływu i zagubienia, szaleją biesy, „nicość nicościuje”, a główne bohaterki, córki pastora, wyrażają wprost to, co wyczuwają wszystkie postacie: że życie jako takie nie ma sensu.

W tym świetle wypada spojrzeć ponownie na kwestię mnogości hermeneutyk. Otóż czy przedstawione dwa podejścia nie są zbyt przeciwstawne i czy eo ipso nie stają się interpretacyjnym wytrychem, skoro można czytać utwory „hermeneutycznie” w perspektywie zarówno „rozjaśniania egzystencji”, jak i eksponowania spowijającego ją mroku? Pisząc o hermeneutyce nowoczesnej i ponowoczesnej, Michał Januszkiewicz twierdzi, iż „opowieści te można rozwijać niezależnie”, ale dodaje, że istnieje między nimi ciagłość, nić tradycji ${ }^{43}$. Opierałaby się ona na Verwindung, pojęciu stosowanym przez Vattima na określenie swoistej krytycznej kontynuacji, przepracowania dziedzictwa ${ }^{44}$. Pytanie, czy radykalizacja hermeneutyki nie przypomina paradoksu łysego: nie da się sprecyzować, ile włosów trzeba utracić, by stać

${ }^{41}$ W. Sadkowski, Proza świata. Szkice do obrazu powieściopisarstwa wieku XX, Warszawa 1999, s. 259.

${ }^{42}$ Zob. na przykład R. Sheppard, Problematyka modernizmu europejskiego, przeł. P. Wawrzyszko, [w:] Odkrywanie modernizmu. Przektady i komentarze, red. R. Nycz, Kraków 1998, s. 71-140.

${ }^{43}$ Zob. M. Januszkiewicz, Kim jestem ja, kim jesteś ty? Etyka, tożsamość, rozumienie, Poznań 2012, s. 49.

${ }^{44}$ Zob. na przykład G. Vattimo, Postnowoczesność $i$ kres historii, przeł. B. Stelmaszczyk, [w:] Postmodernizm. Antologia przekładów, wybór i oprac. R. Nycz, Kraków 1997, s. 133-134. 
się łysym, przejście między stanami jest płynne, jednak różnica między przypadkami skrajnymi - niebłaha. Nie przetnę tego węzła gordyjskiego, zaproponuję natomiast osobiste rozumienie omawianej orientacji jako, za Gadamerem, sposobu czytania bądź postawy ${ }^{45}$. Postawa ta odsyła głównie do hermeneutyki radykalnej, lecz zarazem może być - w myśl frazy z wiersza Leopolda Staffa Przedśpiew - „pogodna mądrym smutkiem”, co oznaczałoby opowiedzenie się po stronie krytycznego czy też ostrożnego zaufania. Z takiego punktu widzenia dekonstrukcja aksjomatów i protez świadomości nie wyklucza otwarcia na pytanie o sens, możliwości pewnej powszechności oraz horyzontu prawdy jako idei regulatywnej ${ }^{46}$.

\section{Nawiedzony dom}

Nawiązałabym do wzmiankowanej metafory „odrzucenia drabiny”, skoro zadaniem hermeneutyki radykalnej jest sprostanie sytuacji drżenia, załamania się znaczeń ${ }^{47}$. Celowo napomknęłam na wstępie o sprawdzaniu rusztowań, nie zaś fundamentów, które ewokują metafizyczne Grund, podczas gdy rusztowanie, według słownika języka polskiego, stanowi „prowizoryczną konstrukcję ułatwiająca wznoszenie lub remont budowli”. To objaśnienie można potraktować jako ciekawą charakterystykę orientacji hermeneutycznej, która akcentuje, po pierwsze, własne bycie prowizorium związanym z określonym momentem dziejowym, po wtóre, swoją przynależność do nieustannego - i nieprzewidywalnego w skutkach ${ }^{48}$ - procesu interpretacji. W przytoczonej definicji zastapiłabym tylko „ułatwiająca” słowem „umożliwiająca”, gdyż „po Caputo” kluczowe zdaje się raczej „odzyskanie trudności bycia", także bycia-w-świecie-interpretacji - z jednej strony przez brak niezawodnej nici Ariadny, z drugiej brak przyzwolenia na anything goes ${ }^{49}$.

${ }^{45}$ Zob. na przykład H.-G. Gadamer, Kim jestem Ja $i$ kim jesteś Ty, [w:] tegoż, Czy poeci umilkna?, oprac. J. Margański, przeł. M. Łukasiewicz, Bydgoszcz 1998, s. 160.

${ }^{46}$ Zob. J. Grondin, Wprowadzenie do hermeneutyki filozoficznej, przeł. L. Łysien, Kraków 2007, s. 27.

${ }^{47}$ Zob. B. Baran, Fenomenologia amerykańska. Studium z pogranicza, Kraków 1990, s. 162.

${ }^{48}$ Według Gadamera „O randze i doniosłości danej interpretacji stanowi przede wszystkim jej oddziaływanie w dziejach, jej szczególna zdolność do porywania wyobraźni przyszłych pokoleń i inspirowania kolejnych odczytań. Te zaś własności nie dają się w żaden sposób zmierzyć i uzasadnić w sposób racjonalny” - P. Dybel, Oblicza hermeneutyki, Kraków 2012, s. 187.

${ }^{49}$ Por.: „Hermeneutyka radykalna nie poszukuje już sensu w tym, co upływa, lecz stara się utrzymać to, co sensowne, «z uwagi na» upływ [...]. [P]ragnie utrzymać możliwość mówienia o sensie [...] z uwagi na zagrożenie utratą tak zwanego odniesienia przedmiotowego, w którym to odniesieniu przedmiot [...] staje się, jest więc rozumiany jako możliwość. [...] hermeneutyka radykalna odcina się od nieograniczonej swobody dekonstrukcji [...] [i] nadal 
„Umożliwiająca” również dlatego, że doświadczenie hermeneutyczne wypada uznać za punkt wyjścia pozostałych. Jak zaznacza Vattimo: „A priori, które umożliwia nasze doświadczenie świata, to Geschick, przeznaczenie-przesłanie, czy też Überlieferung, przekaz. Bycie nie jest, lecz się przekazuje [...]"50.

Problematycznie brzmi natomiast ,wznoszenie lub remont budowli”. O ile Gadamer argumentuje, iż sztuka zawiera „duchową energię porządkująca”, ${ }^{1}$, o tyle nie wiadomo, co z nurtem, który, zamiast „przyrostu bytu”, uwypukla jego ubywanie. Można odpowiedzieć, że ubywanie nie eliminuje przyrostu sensów dzięki budowaniu interpretacji, a z drugiej strony już autor Prawdy $i$ metody nie miał złudzeń odnośnie do szans uzyskania przez istoty dziejowe pełni samowiedzy, żyjemy bowiem uwikłani w nieskończoną rozmowę. W domyśle implikuje to ciagła otwartość na renegocjację własnych poglądów bez popadania w relatywizm niwelujący konkretne inności. I jeśli wedle Heideggera bycie człowiekiem polega na zamieszkiwaniu ${ }^{52}$, to szczególnie $\mathrm{w}$ dobie ponowoczesnej wydaje się ono zamieszkiwaniem $\mathrm{w}$ opowieściach ${ }^{53}$. Przy czym chodzi nie o wygodne umoszczenie się w nich, lecz o odkrywanie w owym locum nieznanych pomieszczeń, wyrw w podłodze, palimpsestów tapet, słowem: „nieswojości”, niesamowitości, tego, co niegdyś w literaturze oddawał motyw nawiedzonego domu ${ }^{54}$. Dziś taką obcość często przedstawia się jako wynik wyparcia ze swojskości współmieszkańców - w Polsce zwłaszcza Żydów i Niemców, po których pozostały tylko bolesne ślady (nie)obecności, niczym w Tworkach Marka Bieńczyka czy Hanemannie Stefana Chwina.

Niemniej uczucie niepokoju w „domu” ma wymiar bardziej elementarny: swojskość ulega zdemaskowaniu - ujawniającemu jej przygodność i status konstruktu - i właśnie nieswojość (atopon) okazuje się, paradoksalnie, swojska, bo podstawowa ${ }^{55}$. Proza opowiadająca o tużpowojennych migracjach na Ziemie Zachodnie, między innymi Piaskowa Góra Joanny Bator, celnie obrazuje owo wyobcowanie - jako splątane korzenie i zakwestionowanie tożsamości oraz jako poczucie braku przystani i azylu - na które reakcją stają się ułomne próby budowania wszystkiego od zera (gdy osobista przeszłość była traumatyczna) albo pietystycznego odtwarzania

jest hermeneutyką (sensu upływu)" - N. Leśniewski, O hermeneutyce radykalnej, Poznań 1998, s. 162 .

${ }^{50}$ G. Vattimo, Al di là del soggetto. Nietzsche, Heidegger e l'ermeneutica, Milano 1989, s. 7, cyt. za: A. Zawadzki, dz. cyt., s. 63.

${ }^{51}$ Zob. H.-G. Gadamer, Sztuka i naśladownictwo..., s. 140.

${ }^{52}$ Zob. M. Heidegger, Budować, mieszkać, myśleć, [w:] tegoż, Odczyty i rozprawy, przeł. J. Mizera, Kraków 2002, s. 131.

${ }^{53}$ Zob. P. Czapliński, dz. cyt., s. 127.

${ }^{54}$ Zob. Z. Dziuban, Obcość, bezdomność, utrata. Wymiary atopii wspótczesnego doświadczenia kulturowego, Poznań 2009, s. 91.

${ }^{55}$ Zob. tamże, s. 99. 
dawnego świata. Co jednak znaczące, w przywołanej powieści, mimo dramatycznych powikłań wszystkich historii rodzinnych i mimo że każdy jest przybyszem (również w sensie ontologicznym), niektóre odmiany inności są dla osadników nieakceptowalne, ksenofobia i dogmatyzm bynajmniej nie zanikaja. Bohaterowie nie dopuszczają więc przekonania, że - jak tłumaczy za Vattimem Zuzanna Dziuban - „Zamieszkiwanie, jako odpowiednik [...] bycia-bez-fundamentów, wiązać się musi [...] z otwarciem doświadczenia na śmiertelność i niekonieczność, na konstruktywny charakter doświadczanej rzeczywistości [...]" ${ }^{\prime 56}$.

Powraca zatem kwestia rusztowań i konstruowania - nie remontu, gdyż ten przywodzi na myśl zastępowanie zużytego lepszym, a przecież nie takie jest nastawienie autora Poza interpretacja wobec metafizyki, wyrażające się w podkreślaniu, że budujemy (niczym bricoleurzy) zawsze z zastanych materiałów, oraz w kategoriach Verwindung, Andenken i pietas. Mamy z nimi do czynienia na przykład w nostalgicznych Opowieściach chłodnego morza Pawła Huellego, których bohaterów łączy niemożność wyartykułowania siebie, poczucie utraty, bezowocne próby pamięciowego odzyskania harmonii, korespondujące ze stwierdzeniem Vattima, iż „Andenken [...] nie może być pojmowane jako wspominanie, które «odzyskuje» bycie jako coś, co możemy spotkać twarzą w twarz; [...] [lecz] jako coś, co można tylko przypominać, a nigdy przed-stawiać" ${ }^{57}$. Jeden z recenzentów nazywa zaś tom Huellego „powtórzeniem wynikajacym z ciagłego poczucia obowiązku względem miejsc i osób" "58, w czym objawia się kolejna kategoria istotna dla hermeneutyki radykalnej, wszak „Powtórzenie jest dynamiką doświadczenia, w którym to, co doświadczane, wymaga, by wciąż od nowa podejmować próby odpowiedniego (właściwego) rozumienia" ${ }^{59}$.

\section{Doświadczenie (w) opowieści}

Wypada dodać, że bohaterowie Opowieści... poszukują też zaginionej Księgi (kojarzącej się z Autentykiem u Schulza), która może obdarzyć ich znaczeniem - w tym przypadku nie wiadomo jednak, czy słowo pisane na pewno ocala. Może po prostu „Literatura, wyrzekając się roszczenia do prawdy w sensie adekwacyjnym, zdolna jest kierować się ku prawdzie rozumianej jako aletheia, będącej skrywającym odkrywaniem świata, który

${ }^{56}$ Tamże, s. 141.

${ }^{57}$ G. Vattimo, Dialogo con Nietzsche, cyt. za: A. Zawadzki, dz. cyt., s. 111.

${ }^{58}$ G. Kozłowski, A Huelle powtarza za morzem..., <http://ksiazki.wp.pl/page,2,rid,2906,tytul,A-Huelle-powtarza-za-morzem,recenzja.html?ticaid=116f94> [dostęp: 7.7.2016].

${ }^{59}$ N. Leśniewski, dz. cyt., s. 161. 
jest już zawsze naszym światem" ${ }^{\prime 0}$. Byłoby to radykalnohermeneutyczne doświadczenie prawdy jako „horyzontu i tła, w którym się skromnie poruszamy na nasz ograniczony sposób"61.

Wobec braku oparcia w Księdze pozostaje „słabe” (w sensie Vattimowskim) oparcie w książkach: „możność wysłuchania opowieści do końca, ergo przed końcem" ${ }^{2}$. Hermeneutyka wysłuchiwałaby każdej opowieści stanowiacej ślad zmagań ze skończonością (nawet poszarpanej, mętnej, pokracznej) $\mathrm{z}$ troską oraz zainteresowaniem - w źródłowym znaczeniu inter-esse, czyli bycia „pomiędzy”, a nie „nad” (charakterystycznego dla „teorii literatury”). Tu właśnie dochodzi do głosu rzeczona pietas i etyczna odpowiedzialność, ważna zarówno dla Gadamera, jak i Vattima czy Caputo ${ }^{63}$. Z tej perspektywy można czytać wcześniejsze mikropowieści Tulli, deprecjonowane jako postmodernistyczne igraszki, de facto zaś upominające się o jednostkowe „historyjki” ludzi zbędnych, obojętnych dla Historii-molocha: „[C]zasem pojawiała się w otwartych drzwiach półprzezroczysta postać sklepikarza [...], którego obecność trwała zbyt krótko, by pozostat wyraźniejszy ślad"64. Narrator Trybów, zakleszczony w maszynerii języka i świadom czekającej go zguby, „rozumie tylko tyle, że musi się cofnąć, ale to znaczy, że nie rozumie nic, i nawet wydaje mu się przez chwilę, że nie ma tu nic do rozumienia. [...] [Jednak] Zadanie narratora to brnaćc naprzód, cokolwiek się wydarzy”"65. Przesłanie takie po trosze przypomina zakończenie Wielu demonów Pilcha: „[P]otem z ciężkimi, bo ciężkimi sercami będziemy żyć dalej. Będziemy żyć dalej, ponieważ żyć trzeba" ${ }^{\prime \prime}$. A gdzie trzeba żyć i gdzie nie ma fundamentów, tam pozostaje interpretowanie, chociaż serce dzięki temu nie stanie się lżejsze. Niemniej hermeneutyka, zgodnie z etymologia, mediuje pomiędzy doświadczeniem autora, bohatera, interpretatora „prywatnego” i interpretatora „zawodowego”, który przybliża tekst doświadczeniu innych. Już z pism Gadamera wyłania się idea, że hermeneutyka towarzyszy doświadczeniu i nie sposób traktować jej jako metody wyznaczenia prawidłowego sensu, co zresztą należy uznać za nieosiagalne. Trzymanie się doświadczenia - unaocznianie specyfiki i złożoności danego przypadku - jest $\mathrm{w}$ interpretacji hermeneutycznej nieodzowne, by nie narazić się na krytykę, że hasło o „wrzuceniu” w określoną kulturę to pustosłowie, że omawiana

${ }^{60}$ M. Januszkiewicz, dz. cyt., s. 79.

${ }^{61}$ G. Vattimo, Wstęp, [w:] tegoż, dz. cyt., s. 14.

62 J. Pilch, Wiele demonów, Warszawa 2013, s. 272.

${ }^{63}$ Por. zobowiązanie, które dla Caputo manifestuje się w cierpiącym, wyniszczonym chorobami lub torturowanym ciele (flesh) - zob. Ł. Czajka, Święta anarchia. Wprowadzenie do radykalnej hermeneutyki Johna D. Caputo, Poznań 2014, s. 66.

${ }^{64}$ M. Tulli, W czerwieni, Warszawa 1999, s. 137.

${ }^{65}$ Taż, Tryby, Warszawa 2003, s. 70.

${ }^{66}$ J. Pilch, dz. cyt., s. 479. 
orientacja pozostaje ślepa na stosunki ekonomiczne, polityczne, płciowe czy rasowe oraz że konkluzje takiej interpretacji są zawsze ogólnikami (na przykład „rozumienie siebie wobec tekstu”). Świadomość partykularności, historyczności i perspektywiczności postaci, pisarza i samego badacza stanowi wszak sedno i siłę hermeneutyki.

Owo odniesienie do konkretnego egzystencjalnego doświadczenia broni ją przed statusem wytrychu, który przemocą otwiera wszystkie teksty ${ }^{67}$. Nie byłaby też ona kluczem, skoro do zamka pasuje wyłącznie jeden wzór ząbków. Nie jest hermeneutyka również dziurką od klucza, przez którą można podpatrzeć coś ukrywanego - tu pozostawia pole „mistrzom podejrzeń”. Wydaje się raczej skromnym wysiłkiem współorganizowania życia w nieustannie budowanym, nieugruntowanym i nigdy nieukończonym domu, konstruowanym z przygodnych i „nie-swojskich” opowieści, ale takim, w którym można zamieszkiwać $z$ sensem.

\section{BIBLIOGRAFIA}

\section{CYTOWANA PROZA}

Bator Joanna, Ciemno, prawie noc, Warszawa 2013.

Dehnel Jacek, Lala, Warszawa 2006.

Oryszyn Zyta, Ocalenie Atlantydy, Warszawa 2012.

Pilch Jerzy, Wiele demonów, Warszawa 2013.

Tulli Magdalena, Tryby, Warszawa 2003.

Tulli Magdalena, W czerwieni, Warszawa 1999.

Tulli Magdalena, Włoskie szpilki, Warszawa 2011.

Woolf Virginia, Do latarni morskiej, przeł. K. Klinger, Warszawa 1962.

HERMENEUTYKA I VARIA

Assmann A., Cztery formy pamięci, przeł. K. Sidowska, [w:] A. Assmann, Między historia a pamięciq. Antologia, red. M. Saryusz-Wolska, Warszawa 2013, s. 39-57.

Baran B., Fenomenologia amerykańska. Studium z pogranicza, Kraków 1990.

Burzyńska A., Kariera narracji. O zwrocie narratywistycznym w humanistyce, [w:]

Narracja i tożsamość, t. 2: Antropologiczne problemy literatury, red. W. Bolecki,

R. Nycz, Warszawa 2004, s. 7-27.

Burzyńska A., Markowski M.P., Teorie literatury XX wieku. Podręcznik, Kraków 2006. Caputo J.D., Demythologizing Heidegger, Bloomington-Indianapolis 1993.

${ }^{67}$ Por. zarzuty Caputo wobec Heideggera, który zapomniawszy o „logice faktyczności”, wszystkich interpretowanych poetów wyabstrahował z ich historycznej egzystencji i jednostkowego cierpienia, by uczynić z nich heroldów prawdy Bycia - zob. J.D. Caputo, Demythologizing Heidegger, Bloomington-Indianapolis 1993, s. 70, 143, 149. 
Caputo J.D., Radical Hermeneutics. Repetition, Deconstruction and the Hermeneutic Project. Indianapolis 1987.

Chrzastowska B., Wysłouch S., Poetyka stosowana, Warszawa 2000.

Culler J., Teoria literatury, przeł. M. Bassaj, Warszawa 1998.

Czajka Ł., Święta anarchia. Wprowadzenie do radykalnej hermeneutyki Johna D. Caputo, Poznań 2014.

Czapliński P., Mapa, córka nostalgii, [w:] P. Czapliński, Wznioste tęsknoty. Nostalgie w prozie lat dziewięćdziesiatych, Kraków 2001, s. 105-128.

Dybel P., Oblicza hermeneutyki, Kraków 2012.

Dziuban Z., Obcość, bezdomność, utrata. Wymiary atopii wspótczesnego doświadczenia kulturowego, Poznań 2009.

Gadamer H.-G., Aktualność piękna. Sztuka jako gra, symbol i święto, przeł. K. Krzemieniowa, Warszawa 1993.

Gadamer H.-G., Kim jestem Ja i kim jesteś Ty, [w:] H.-G. Gadamer, Czy poeci umilkna?, oprac. J. Margański, przeł. M. Łukasiewicz, Bydgoszcz 1998, s. 67-165.

Gadamer H.-G., Prawda i metoda. Zarys hermeneutyki filozoficznej, przeł. i wstęp B. Baran, Warszawa 2007.

Gadamer H.-G., Sztuka i naśladownictwo, przeł. M. Łukasiewicz, [w:] H.-G. Gadamer, Rozum, stowo, dzieje. Szkice wybrane, wybór, oprac. i wstęp K. Michalski, Warszawa 1979, s. 128-141.

Grondin J., Wprowadzenie do hermeneutyki filozoficznej, przeł. L. Łysień, Kraków 2007.

Heidegger M., Budować, mieszkać, myśleć, [w:] M. Heidegger, Odczyty i rozprawy, przeł. J. Mizera, Kraków 2002, s. 127-143.

Januszkiewicz M., Kim jestem ja, kim jesteś ty? Etyka, tożsamość, rozumienie, Poznań 2012.

Jarzębski J., Kariera „autentyku”, [w:] J. Jarzębski, Powieść jako autokreacja, Kraków 1984, s. 337-364.

Jarzębski J., „Traktat o łuskaniu fasoli” W. Myśliwskiego, <http://www.instytutksiazki. pl/ksiazki-detal,literatura-polska,1957,traktat-o-luskaniu-fasoli.html> [dostęp: 16.07.2016].

Koziołek R., Teoria literatury jako akt wiary, [w:] Teoria nad-interpretacja?, red. J. Olejniczak, M. Baron, P. Tomczok, Katowice 2012, s. 12-29.

Kozłowski G., A Huelle powtarza za morzem..., <http://ksiazki.wp.pl/page,2,rid,2906,tytul,A-Huelle-powtarza-za-morzem,recenzja.html?ticaid=116f94> [dostęp: 7.7.2016].

Kuligowski P., Humanistyka jako hermeneutyka, Wrocław 2007.

Leśniewski N., O hermeneutyce radykalnej, Poznań 1998.

Markowski M.P., Czarny nurt: Gombrowicz, świat, literatura, Kraków 2004.

Markowski M.P., Historia i metafizyka, [w:] Teraźniejszość i pamięć przeszłości. Rozumienie historii w literaturze polskiej XX $i$ XXI wieku, red. H. Gosk, A. Zieniewicz, Warszawa 2006, s. 32-45.

Marquard O., Pytanie o pytanie, na które odpowiedzia jest hermeneutyka, [w:] O. Marquard, Rozstanie z filozofia pierwszych zasad. Studia filozoficzne, przeł. K. Krzemieniowa, Warszawa 1994, s. 120-150.

Potępa M., Nihilizm i hermeneutyka $w$ filozofii G. Vattimo, [w:] Uniwersalny wymiar hermeneutyki, red. A. Przyłębski, Poznań 1997, s. 81-108. 
Ricoeur P., Czas i opowieść, t. 2: Konfiguracja w opowieści fikcyjnej, przeł. J. Jakubowski, Kraków 2008.

Ricoeur P., Konflikt hermeneutyk: epistemologia interpretacji, przeł. J. Skoczylas, [w:]

P. Ricoeur, Egzystencja i hermeneutyka. Rozprawy o metodzie, oprac. S. Cichowicz, Warszawa 1985, s. 124-146.

Ricoeur P., O interpretacji. Esej o Freudzie, przeł. M. Falski, Warszawa 2008.

Ricoeur P., O sobie samym jako innym, przeł. B. Chełstowski, oprac. M. Kowalska, Warszawa 2003.

Ricoeur P., Przyswojenie, [w:] P. Ricoeur, Język, tekst, interpretacja. Wybór pism, wybór i wstęp K. Rosner, przeł. P. Graff, K. Rosner, Warszawa 1989, s. 272-289.

Ricoeur P., Tożsamość osobowa, [w:] P. Ricoeur, Filozofia osoby, przeł. M. Frankiewicz, Kraków 1992, s. 33-44.

Sadkowski W., Proza świata. Szkice do obrazu powieściopisarstwa wieku XX, Warszawa 1999.

Sheppard R., Problematyka modernizmu europejskiego, przeł. P. Wawrzyszko, [w:] Odkrywanie modernizmu. Przektady i komentarze, red. R. Nycz, Kraków 1998, s. 71-140.

Szulakiewicz M., Filozofia jako hermeneutyka, Toruń 2004.

Vattimo G., Koniec nowoczesności, przeł. M. Surma-Gawłowska, wstęp A. Zawadzki, Kraków 2006.

Zawadzki A., Literatura a myśl słaba, Kraków 2009. 
